\title{
Rural Non-Farm Micro-Entrepreneurship or Not: Gender Issue in Decision Making
}

\section{Bhabesh Hazarika and Kishor Goswami}

Department of Humanities \& Social Sciences, Indian Institute of Technology Kharagpur, India

\section{Corresponding Author}

Bhabesh Hazarika, M. A.

Research Scholar (Economics)

Department of Humanities \& Social Sciences

Indian Institute of Technology Kharagpur

West Bengal 721 302; India

Fax +913222 $282270 / 255303$

E-mail: bhabesh86@hss.iitkgp.ernet.in

\begin{abstract}
The expansion of female intensive sectors due to globalization and trade liberalization engenders ample employment and income opportunities for female and thus female entrepreneurship. Despite an increase in the female entrepreneurship in recent decade, females are still outnumbered in entrepreneurial activities by the male. The determinants that influence the decision to become an entrepreneur substantially differ across gender. Present study provides empirical evidences towards individuals' entry into rural non-farm microentrepreneurship focusing on gender issue. Based on primary data collected in Assam, the study found that the probability of becoming a micro-entrepreneur is more for being a female in the female intensive industry. The results reveal the existence gender differences with respect to magnitude and direction in the determinants of micro-entrepreneurship development. The influence of educational attainment is not found significant for female’s probability to become a handloom micro-entrepreneur. Financial inclusion of rural people coupled with proper utilization of credit accessed is crucial in handloom micro-enterprise development.
\end{abstract}

Keywords: Rural, Non-farm, Micro-entrepreneurship, Gender, Handloom, Assam 


\section{Rural Non-Farm Micro-Entrepreneurship or Not: Gender Issue in Decision Making}

\section{Introduction}

Promoting rural non-farm micro-entrepreneurship (RNFM) is widely established as an important phenomenon towards local economic development and growth. Policy makers often emphasizes on bringing more people into entrepreneurial activities to achieve different development goals such as employment and income generation, innovation, reduction of rural-urban migration, and elimination of poverty. While the related entrepreneurial literatures undoubtedly enhance our understandings towards entry into entrepreneurial activities (Oostendrop 2009; Leoni and Falk 2010; Amorós and Bosma 2014; Saridakis et al. 2014), the tendency of the mainstream literature is to focus on the issues in developed economics leaving the developing economies in fringe (Oostendrop 2009; Peris-Ortiz et al. 2012; Web et al. 2013). This results in scarce knowledge with respect to nature, opportunities, and challenges encountered by the rural non-farm micro-entrepreneurs in developing economies such as that in India.

Researches established that females are outnumbered in entrepreneurial activities by the male (Leoni and Folk 2010; Web et al. 2013; Gindling 2014). However, there is an increase in the female entrepreneurship in recent decade (Parker 2009; Peris-Ortiz et al. 2012). The expansion of female intensive sectors due to globalization and trade liberalization engenders ample employment and income opportunities for female (Aguayo-Tellez et al. 2013; Contessi et al. 2013). These also have positive effects in the informal sector towards female employment and important implications towards female RNFM development. Existing data suggest that in many developing countries, the informal sector is a major source of employment for economically active female (UN 2010). In India, nearly 90 percent non-agriculture female employments are informal employment (UN 2010). Widespread unemployment coupled with gender discrimination in the formal labor market push more and more female into small and micro-entrepreneurship. Though female entrepreneurship in the informal sector concentrates around small size and low growth activities, it provides the opportunity to earn money which further strengthens women's economic status and ultimately women empowerment (Welter and Smallbone, 2008). Moreover, evidence shows that about half of females engaged in self-employment/microentrepreneurship take it as part-time activity and operated within home (Thompson et al. 2009) that provide them work flexibility to mitigate the household responsibilities (Duberley and Carrigan 2013). Thus selfemployment/micro-entrepreneurship in the non-farm informal sector may be portrayed in substituting such parttime employment (Georgellis and Wall 2005; Saridakis et al. 2014) and it can be possible to witness a reverse scenario that female may be more interested than male to engage in self-employment or micro-entrepreneurial activities in the female intensive sectors.

Though many scholars' conceptualizations on RNFM development are in similar directions, their findings show different directions of influences and conclusions of a few determinants with regard to their relative importance (Linan et al. 2011; Simoes et al. 2013; Thai and Turkina 2013). Considerable efforts have been put on explaining the existing gender gap in the entrepreneurial participation as well as on performance, yet potential role of female micro-entrepreneurship remains under researched. In many cases, there exists gender effects in the magnitude and direction of influence of determinants associated with micro-entrepreneurship development. This suggests existence of gender based obstacles as well as potential for achieving greater gender equality and welfare gains if reasons can be understood and addressed through policy prescription and 
implementation (Oostendrop 2009; Acs et al. 2011; Saridakis et al. 2014). This brings also into the picture the importance of understanding what drives individuals especially the female into RNFM in developing economies.

Considering the above perspectives, present study tries to provide empirical evidences for the determinants of RNFM entry focusing the gender issue in Assam, a state from North East India. It looks into the aspect "do the different determinants of micro-entrepreneurship affects male and female differently towards RNFM entry”. Based on primary data collected at household level, which provide ground reality with respect to what influence rural people to take-up micro-entrepreneurial activities, present study draws insights for one’s career choice decision towards RNFM from an under researched context of handloom industry. Thus, it contributes towards understanding of multifaceted entrepreneurship domain in the context of RNFM from developing economy which is of policy interest in why some people enter into micro-entrepreneurship while others not. The findings can be extended to other RNFM industries such as handicraft, bamboo, jute, non-timer forest products, and agro-processing industries.

\section{RNFM in informal economy and gender}

The informal sector refers to the economic activities outside the formal intuitional economies but taken place in an economy with social acceptance (Web et al. 2013). The promotion of RNFM is important as it has implications for absorption of labor force (mainly unskilled and semi-skilled) and equality of income distribution through employment generation (Oostendrop 2009) and is of policy interest in the developing economies. Thai and Turkina (2013) conceptualized four key issues ${ }^{1}$ of why the informal economy cannot be ignored and why the RNFM issues need more attention from the academic communities. RNFM remains legitimate for a large section of population in a country that provides support to their livelihood (Rutherford and Butler 2007). Though not necessary, deregulated small and micro-enterprises, family enterprises, home based enterprise, and self-employment activities often regarded as the potential manifestation of informality.

RNFM in informal sector is emerged as a result of opportunity or necessity or a combination of both. While opportunity driven individuals perceive micro-entrepreneurial activities as a platform to expand their income level, achieve greater autonomy, and work-flexibility, these are often regarded as the only source of income facing lack of alternative means of livelihood for the others (Williams and Gurtoo 2011). The survivalist-type activities lead to expansion of RNFM even during economic downturn as they are more resilient and flexible (Liedholm 2002). Thus, through provisions of opportunity, employment, and income generation, RNFM may facilitate economic and social stability in developing economies.

Researches established that females are less likely to involve in entrepreneurial activities (Leoni and Folk 2010; Gindling 2014). The household and family obligations often restrict their mobility outside home and often the higher marginal utility of time spent in home is the cause of lower rate of female microentrepreneurship (Kevane and Wyndic 2001). Apart from that, female are constrained by low level of education, low business skills, innumeracy, and low access to productive resources in developing economies (Vossenberg

\footnotetext{
1 First, informal economy occupies a sizeable share in GDP of any economy. Second, informal economy is highly prevalent in certain countries. Third, informal entrepreneurship takes places in all countries regardless of their level of economic development. Fourth, informal entrepreneurship can be vulnerable to unethical practices (e.g., corruption, worker exploitation, and natural environment abuse).
} 
2013). Moreover, inequality in market access $^{2}$ is another issue involved in female participation in RNFM narrowing their range of activities. However, females have the potentials towards RNFM and economic development. The expansion of female intensive sectors in informal economy such as textiles, handlooms, garments, ladder, agricultural processing industries, etc., are engendering ample employment and income opportunities which has important implications in female RNFM development (Aguayo-Tellez et al. 2013; Contessi et al. 2013). Thus, to a greater extent, it addresses the existing gap in entrepreneurial involvement. Therefore, for female, the RNFM provide a scope to come out from the subordination and helps in bringing them to mainstream labor force and ultimately the local economic development.

\section{Individual level determinants of RNFM entry and gender}

Literatures suggest that one's decision to enter into entrepreneurship/micro-entrepreneurship is influenced by a host of micro-economic determinants (Verheul et al. 2012; Thai and Turkina 2013; Saridakis et al. 2014). At individual level, individual's age, gender, education, work experience, etc., significantly influence his/her entry into RNFM. The relation between a particular determinant and the outcome like 'becoming a micro-entrepreneur' may give diverse conclusions due to sector specific determinants (Web et al. 2013). These kind of diverse and unclear conclusions contemplate that the same determinant may have a different impact in different context (Linan et al. 2011). Although conceptualizations of many scholars on entrepreneurial development shows similar directions, their findings show different directions of influence and conclusions with regard to the relative importance of a few determinants (Simoes et al. 2013; Thai and Turkina 2013). Several other studies also demonstrated that a particular determinant may have a positive (Parker 2009), a negative (Verheul et al. 2012), a U-shape (Poschke 2013) or even no relationship at all (Stel et al. 2007). There also exists a body of literature those establish gender disparities with evidences that female micro-entrepreneurs have different characteristics and they are influenced differently towards micro-entrepreneurship entry (Georgellis and Wall 2005; Leoni and Folk 2010).

Many of the RNFM start-up requires some sector specific basic knowledge and indigenous skills. A few of them are characterized to be intergenerational and home based type such as handloom activities. Individuals' age as a proxy for experience play important role in choosing an occupation in the domain of RNFM (Bharadwaj et al. 2013; Bortamuly et al. 2013). The experience gained over years likely to help individuals in focusing associated problems, customers' requirements (Bhagavatula et al. 2010; Kotha and Goerge 2012), and make aware of own needs and source of resources (Hellmann and Puri 2002). The microentrepreneurs and employees in informal sector often have the on-the-job experience which leads to acquisition of skills and knowledge, and expansion of social network. These lead to accumulation of human as well as financial capital (Parker 2009; Cahill et al. 2013) that enhances individual capability and confidence in starting a micro-enterprise.

Education and training (represents human capital) provide the necessary skills to operate efficiently and feasibly an enterprise (Bortamuly et al. 2013; Lofstrom et al. 2014). Entrepreneurial training is perceived to be very effective and fosters the entry into micro-entrepreneurial activities in the rural non-farm sector (Linan et al. 2011). Lower level of education often force people enter into informal and traditional entrepreneurial activities.

2 Kantor (2005) found that 30 percent of female micro-entrepreneurs in Gujrat, India sell their product at their firm due to lack of marketing linkages while for male the figure is 20 percent. 
A few scholars have found gender effect of education on micro-entrepreneurial entry in the rural areas resulting lower rate of female's entry (Parker 2009). Given the traditional and informal sector, education may not be a binding constraint in dealing with the stakeholders in such business (Mahmood 2009). Thus, the net effect of education on entrepreneurship occupation choice is still unclear.

The role of access to credit is inevitable in entry as well as functioning and expanding of RNFM (Bruder et al. 2011; Bortamuly et al. 2013). In many times, the financial exclusion becomes a hurdle in accessing the productive resources for the micro-entrepreneurs operating in the informal economy. This limits their scope even if they are aware of the opportunities opened to them. Here, the gender effect in relation to credit issues may appear to be critical in explaining the lower rate of females' entry into RNFM (Bruder et al. 2011; Nachimuthu and Gunatharan 2012). The lower rate of entrepreneurship entry of female can explained through their lack of capital/credit access. This may be because most of the female in the rural areas are lack of some fundamental qualities such as they are not highly educated and are unaware in handling the legal and other formalities involve in accessing formal credit facilities (Mehta and Mehta 2011; Rijkers and Costa 2012). This lowers the rate of female's entry into RNFM even if many of the female possess indigenous knowledge and skills to run a RNFM. Furthermore, cultural/social norms and values also mitigate female’s entry into RNFM.

While credit constraints limit the scope of micro-entrepreneurial activities in the rural areas, social capital $^{3}$ can revitalize the RNFM and thereby the local community development. Business network in terms of the number of people connected with a business and the frequency of interaction with them is one of the dimensions of social capital that greatly facilitates one's involvement in micro-entrepreneurial activities (Runyan et al. 2004; Bhagavatula et al. 2010). This kind of relationship not only helps in product mobilization, raw material access, and access to market but also serves as credit sources (Wydick et al. 2011). Social capital emerges crucial for female micro-entrepreneurs as this facilitates access to capital/credit through their personal, family and community network (Bhagavatula et al. 2010). While formal institutions (especially micro-finance) operating within informality are unable to function properly with limited outreach, traders and the middlemen are often found to provide working capital to the RNFM. Such business networks are crucial for the craft based enterprises in the rural areas such as handloom to acquire market information and resources to satisfy the highly differentiated, uncertain, and fragmented demand condition (Bhagavatula et al. 2010).

Family as a source of social capital play important role in RNFM entry especially for females. Family emerges as a source of free labor (full-time or part-time) and/or finance. Apart from that, having a business history in the family also significantly influences young people to take up entrepreneurial activities ensuring intergenerational sustainability of the family businesses (Chlosta et al. 2012; Schroder and Schmitt-Rodermund, 2013). The early entrepreneurial (Carr and Sequeira 2007), pro-business attitude (Dunn and Holtz-Eakin 2000), and established business networks of parents (Bhagavatula et al. 2010) result in entrepreneurial competence (Obschonka et al. 2011) in young people that positively influence their decision to enter into microentrepreneurship.

3 Social capital basically represents the relational embeddedness among people whether formal or informal. The information and resources may be obtained through goodwill and trust in relational transactions. Relational exchanges are regarded to be capital in the sense that knowledge may be appropriated from a region's social network structure that results in positive resources, skills and network externalities for individuals. 


\section{Conceptual model}

Considering the depth and importance of the handloom micro-entrepreneurship study, it is conceived that a firm level model of micro-entrepreneurship development will be appropriate, since the decision of entry into microentrepreneurship is an individual level phenomenon. The promotion of such micro-entrepreneurship in the informal sector in rural areas is of policy interest in the developing economies as it has implications for absorption of labor force (mainly unskilled and semi-skilled) and equality of income distribution through employment generation (Oostendrop, 2009). Based on the literature, a conceptual model of handloom microentrepreneurship development is proposed for a better understanding of the contextual as well as few underlying variables. It thus gives emphasis on identifying the variables those motivate individuals towards microentrepreneurship in the handloom industry. The conceptual model is presented in Figure 1.

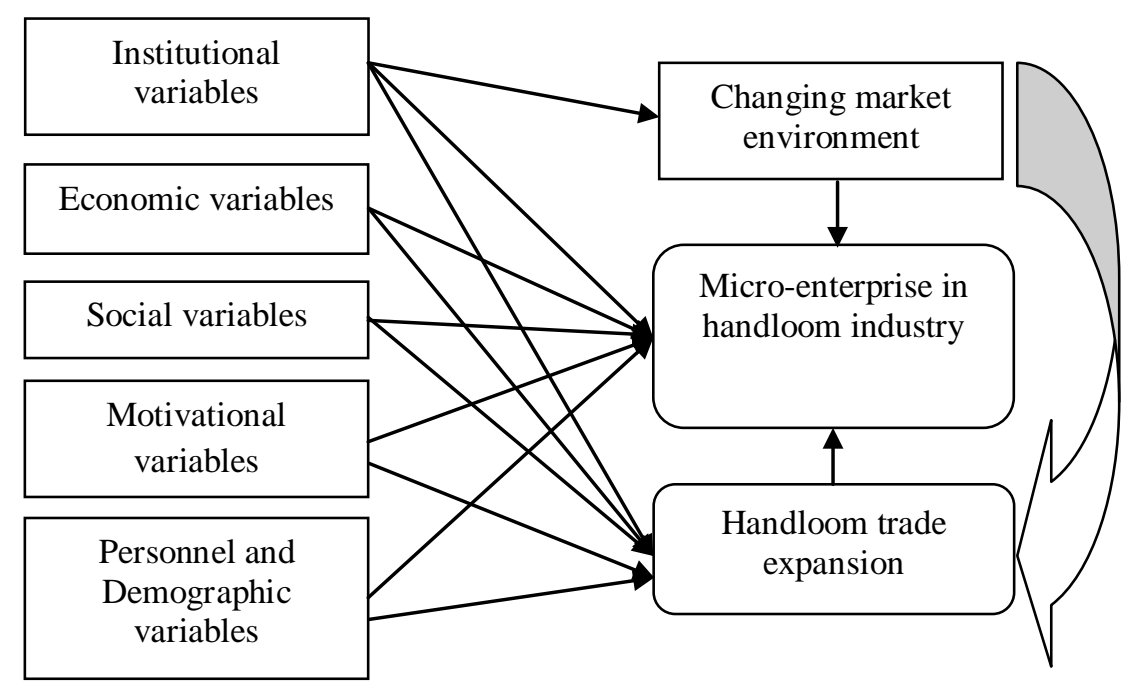

Figure 1: Conceptual framework for micro-enterprise development in the handloom industry

Individuals' entry into micro-entrepreneurship in handloom industry is conceptualized as a function of a set of personal and demographic, economic, institutional, and social variables. Personal characteristics such as age, educational attainments, handloom training, work and other handloom related experiences significantly influence an individual in becoming a micro-entrepreneur in the industry. Individuals involved in the industry often have the on-the-job experience which leads to acquisition of skills and knowledge, and expansion of social network. These lead to accumulation of human as well as financial capital (Parker, 2009; Cahill et al., 2013) that enhances individual capability and confidence in starting a micro-enterprise. The experience gained over years likely to help individuals in focusing associated problems, customers' requirements (Bhagavatula et al., 2010; Kotha \& Goerge, 2012), and make aware of own needs and source of resources (Hellmann \& Puri, 2002). Moreover, there exist few underlying dimensions which significantly motivate individuals to become a handloom micro-entrepreneur. For example, The desire to become economically independent, enjoying a decent social status, risk behavior, achieving financial security, providing support/better lifestyle for their family, etc., significantly influence individuals towards micro-entrepreneurial activities (McGowan et al., 2012).

Economic condition of the individuals gives rise to either survivalist or opportunist type of microentrepreneurship. As handloom activities are traditionally practiced in the rural areas of Assam, handloom micro-entrepreneurship becomes a viable option these individuals. Individuals who are constrained by meager employment/income opportunities and increasing pressure on agriculture are often found to switching from 
domestic production to commercialization of handloom products i.e., entrepreneurial activities. On the other hand, there exist individuals who choose handloom micro-entrepreneurship to raise their income seizing the opportunities in the market. In both cases, individual income emerges crucial as higher income level gives financial strength, borrowing ability, and confident to open up a micro-enterprise on their own or take over the family business (Bortamuly et al., 2013). Moreover, higher income makes individuals self-reliant and empowered, particularly the rural female, which influence them in making decision towards microentrepreneurial activities.

Institutional variables such as access to credit, access to training, marketing linkages, etc., are crucial towards micro-entrepreneurship development in rural informal sectors such as handloom. Favorable conditions in these aspects help individuals towards in-house mechanization (e.g., dobby, jacquard, and spinning machines), supply chain management (particularly raw materials such as yarn, dye, and zari), product diversification, etc., and thus increase the probability of entering into handloom micro-entrepreneurship. In rural areas, individuals are more dependent on internal sources of finance such as personal saving, family income, and other informal sources than external sources like banks and other formal credit sources to finance handloom activities. Here, handloom social capital/network of an individual plays an important role in creating a positive environment towards micro-entrepreneurial involvement.

Social capital basically represents the relational embeddedness among individuals whether formal or informal. The information and resources may be obtained through goodwill and trust in relational transactions. Relational exchanges are regarded to be capital in the sense that knowledge may be appropriated from a region's social network structure that results in positive resources, skills and network externalities for individuals. The linkage between an individual and interconnected stakeholders particularly in handloom industry such as master weavers, traders, other input suppliers, output buyers, and associated institutions constitute the handloom social capital/network. These are crucial for handloom and other the craft based enterprises in the rural areas to acquire market information and resources to satisfy the highly differentiated, uncertain, and fragmented demand condition (Bhagavatula et al., 2010). Theses not only helps in product mobilization, raw material access, and access to market but also serves as credit sources (Wydick et al., 2011) and thus influence individuals towards micro-entrepreneurial development in the industry.

Moreover, the changing market environment brings ample opportunities as well as competition as well as to expand the handloom business. The removal of trade restrictions (e.g., MFA) in the textile sector resulted reorientation in the production and market for textile products leading to led to an expansion in the economy. Here, initiatives taken at governments' level further speed up the process with proper orientation and effective participation of individuals concerned. Existence of asymmetry information between the loan aspirants and formal credit institutions prevents the micro-entrepreneurs in rural informal sectors from getting financial assistances. Therefore, government interventions are essentials to correct gender segregation for nurturing the entrepreneurial orientation in an economy.

\section{Analytical model and empirical estimation}

The analytical framework for the present study is based on a household production-leisure model where the production, consumption, and work related decisions are brought into a single framework. It is assumed that household production and consumption decisions are not separable in the context of rural informal sector in the developing economies where the production decisions are much influenced by a host of socio-demographic, 
economic, and institutional determinants. The proposed model of occupational choice in the handloom industry within RNFM context is based on the expected utility maximization framework (Douglas and Shepherd, 2002; Bharadwaj et al. 2013). The proposed model assumes that there are two career options in the handloom industry i.e., micro-entrepreneur and paid employee ${ }^{4}$.

The engagement in any activity in the handloom industry depends on a number of determinants including economic $\left(E_{\mathrm{ji}}\right)$, personal and demographic $\left(D_{\mathrm{ji}}\right)$, social $\left(S_{\mathrm{ji}}\right)$, and institutional $\left(I_{\mathrm{ji}}\right)$ those give an individual the utility. Thus, the utility function can be linked with these determinants in the form of:

$$
U_{j i}=f\left(D_{j i}, E_{j i}, I_{j i}, S_{j i} ; \delta\right)+\epsilon_{j i}
$$

where $U_{\mathrm{ji}}$ is the utility derived from the chosen occupation, $\delta$ is parameterization of the utility function, and $\varepsilon_{\mathrm{ij}}$ is the error term. Given the career choices opened to an individual in the handloom industry, individual compares expected net utility $\left(E U^{*}\right)$ of being a micro-entrepreneur or a handloom paid worker and chose he/she chooses the one that is expected to maximize the total utility over the planned horizon (Baumol 1990; Douglas and Shepherd 2002). Since utility $U_{\mathrm{ij}}$ is random ${ }^{5}$, the individual ' $\mathrm{i}$ ' choose entrepreneurship over paid employment in the handloom industry if $E U_{1 i}>E U_{2 i}$. Thus, for an individual ' $\mathrm{i}$ ' in the handloom industry, the probability of engage in the handloom industry is given by:

$$
\begin{aligned}
\operatorname{Pr}\left(\mathrm{Z}^{*}=1\right)= & \operatorname{Pr}\left(E U_{1 i}>E U_{2 i}\right) \\
& =\operatorname{Pr}\left[\left\{f_{1}\left(D_{1 i}, E_{1 i}, I_{i 1}, S_{1 i} ; \delta_{1}\right)+\epsilon_{1 i}\right\}>\left\{f_{2}\left(D_{2 i}, E_{2 i}, I_{2 i}, S_{2 i} ; \delta_{2}\right)+\epsilon_{2 i}\right\}\right] \\
& =\operatorname{Pr}\left[\left(\epsilon_{1 i}-\epsilon_{2 i}\right)>\left\{f_{2}\left(D_{2 i}, E_{2 i}, I_{2 i}, S_{2 i} ; \delta_{2}\right)-f_{1}\left(D_{1 i}, E_{1 i}, I_{i 1}, S_{1 i} ; \delta_{1}\right)\right\}\right] \\
& =\operatorname{Pr}\left[\left(\epsilon_{1 i}-\epsilon_{2 i}\right)>f_{j}\left\{\left(D_{j i}, E_{j i}, I_{j i}, S_{j i} ;\left(\delta_{2}-\delta_{1}\right)\right\}\right.\right. \\
& =\operatorname{Pr}\left[\left(\gamma_{i}\right)>F_{j}\left\{\left(D_{j i}, E_{j i}, I_{j i}, S_{j i} ; \delta\right)\right\}\right. \\
& =\psi_{\gamma}\left(X_{i} \delta\right)
\end{aligned}
$$

where $\psi_{\gamma}$ is the cumulative distribution function for the random variable $y$.

The net utility can be expressed in a reduced form as:

$$
E U^{*}=X_{i} \delta+\varepsilon_{i}
$$

where $X_{i}$ is the vector of explanatory variables and $\delta$ is the vector of coefficients to be estimated. Since utility is random and the true net utility is never known, inclusion of the error term $\varepsilon_{i}$ bring randomness to the utility function to be estimated.

There are numerous occupational choice studies using different models such as Linear Regression Model, Non-linear Probabilistic Models, Generalized Linear Models, etc., depending upon the nature of the dependent variable for analyzing the influence of different independent variables (Gujarati 2004; Wooldridge 2009). In case of binary dependent variable, the Logit and Probit models are used frequently (Leoni and Falk 2010; Verheul et al. 2012; Bharadwaj et al. 2013; Bortamuly et al. 2013). There is no strong theoretical justification to judge the superiority of one model over another. Though both Probit and Logit models produce similar results, the models differ in specification of the distribution of the error term (Gujarati 2003). Probit

\footnotetext{
4 A handloom micro-entrepreneur in the present study is defined as an individual who owns a handloom micro-enterprise with or without paid employee and takes the decision regarding the firm activities. As the industry is low capital intensive and requires more physical labor, two additional assumptions were considered in defining a handloom micro-entrepreneur. First, they may have a maximum of 10 laborers or 10 operating looms in the survey year. Secondly, they should have at least one year of entrepreneurial experience in the industry during the survey period. On the other hand, non-entrepreneurs category includes individuals who are engaged in the industry as a paid employee such as weavers, reelers, part-time workers, etc.

5 Takes any value but follows a probability distribution.
} 
model is used when the cumulative distribution of the error term is assumed to be normal, and Logit model is applied when the distribution of the error term is assumed to be logistic. In Probit model, several specification problems can more easily be avoided because of the normal distribution of the error term (Wooldridge 2009). For the present study, a binary Probit model is proposed to analyze the occupational decision in the handloom industry whether an individual prefer micro-entrepreneurship or not.

The model estimation for micro-enterprise development in the handloom industry is formulated based on the work of Verheul et al. (2012). Individual 'i’ chooses to engage in handloom micro-entrepreneurship if the expected utility derived from being a micro-entrepreneur is greater than that of paid employee. The Probit model assumes that while the dependent variable is observed to be taken binary values, there is actually a latent, unobserved continuous variable that determines the value of the dependent variable. Assuming the error term to be normally distributed, the proposed Probit model is:

$$
J^{*}=X \beta+\varepsilon
$$

where $J^{*}$ is a latent variable measuring the probability of becoming a micro-entrepreneur in the handloom industry, $\mathrm{X}$ is a vector of independent determinants includes a range of economic, societal, institutional, and personal characteristics in the handloom micro-entrepreneurship development ${ }^{6}$. Though $\nabla_{i}^{*}$ is not directly observable, one can observe it by defining the latent variable $J_{A}^{*}$ equal to 1 if the household is a handloom microentrepreneur, and 0 for paid employee i.e.,

$$
J_{A}=\left\{\begin{array}{l}
1 \text { if } J_{A}^{*}>0 \\
0 \text { if } J_{A}^{*} \leq 0
\end{array}\right.
$$

Since the dependent variable is latent in nature, applying ordinary least square (OLS) will be inefficient. Maximum likelihood estimates (MLEs) of the coefficients and their corresponding standard errors may be captured which are asymptotically normal, consistent, and efficient ${ }^{7}$. Since MLEs are based on the distribution of dependent variable $(Y)$, given the independent variable $(X)$, the heteroskedasticity in $\operatorname{Var}(\mathrm{y} / \mathrm{x})$ is automatically accounted for (Wooldridge 2009).

\section{Background, sampling procedure, and nature of data}

\section{Background of handloom industry in Assam}

For understanding the determinants and motivation towards entry into RNFM, the handloom industry in Assam, a state from North East India is considered in the present study. Special attention is given to handloom specific issues as the industry comes within a traditional, rural non-farm, and low technology based industrial setup. The handloom industry falls under the informal sector and by considering micro-entrepreneurship in the context, the present study focuses upon an under-researched sector in a developing country. The industry provides a suitable setting to study the importance and contribution of RNFM towards local economic development (Niranjana 2001; Syamasundari and Niranjana 2006; Bhagavatula et al. 2010; Bortamuly et al. 2013).

The industry is unorganized and production takes place mostly in rural areas. During 2009-10, handloom employment was about 4.33 million in India covering weavers and allied workers, which include 3.85 million adult weavers. Of the latter, 77.90 percent are female. This is more so in Assam, as the state possess

\footnotetext{
6 Initially three more variables viz., desire to become self-dependent and total incomes of the family members from other sources (i.e., excluding income from handloom activities) were included in the model. However, due to high pair-wise correlation with the other independent variables and multicollinearity problem, these variables were excluded from the final model.

7 Since the dependent variable is latent in nature, applying ordinary least square (OLS) will be inefficient.
} 
1.11 million (46.76\%) looms and 1.24 million (44.30\%) handloom households of India. The share of female in the handloom labor force is 98.96 percent in the state (NCAER 2010).

Weaving plays an effective role in socioeconomic development of the economically weaker section in the rural areas of Assam. However, the entrepreneurial orientation in the handloom industry in the state is mostly unorganized, informal, at an early stage, and commercialization of handloom products is still very less. According to NCAER (2010), only 26.02 percent of the total handloom households are involved in fully commercialized activities in the state against the national figure of 53.09 percent. The industry in the state also characterized with poor adoption of modern technology where a significant number of the handloom households are working with the traditional technology such as throw shuttle loom, fly shuttle looms, etc., which results in a lower productivity. Unlike many low technology based industries, micro-entrepreneurship in the handloom industry is not much examined in assessing its contribution towards micro-entrepreneurship development. There is a need to study the determinants those facilitate a transition from individual level household production activities into full-time commercial production activities.

\section{Sampling procedure}

The study is based on individual level primary data collected from six districts namely Kokrajhar, Baksa, Kamrup, Udalguri, Lakhimpur, and Dhemaji of Assam during January 2012 to June 2012 (Map). The study used a multi-stage sampling technique where the districts were selected following stratified sampling method to capture the different aspects of spatial diversities. Using the data form Statistical Handbook of Assam 2010 (Directorate of Economics and Statistics 2011), all the 27 districts in the state were first distributed into three strata based on the proportion of full-time handloom households to the total handloom households in the state which is 10.48 percent. The first stratum included the districts with higher proportion than the state figure of 10.48 percent. The second stratum included the districts with the proportion close to the state figure, and the last stratum included the districts with lower proportion value than the state figure. Considering the constraints during the data collection process, two districts from each stratum and two blocks from each district were purposively selected for primary data collection.

\section{Map here}

The sample consists of two groups of respondents namely micro-entrepreneur and paid employee. Before collecting the primary data in each village, a list of the households engaged in full-time handloom activities was prepared. A maximum of 15 percent of the total full-time handloom households in each village were randomly selected as the sample units. Thus, a total of 520 respondents were interviewed with a semistructured interview schedule covering various aspects of handloom micro-entrepreneurship such as motivation, productions, output, input requirement, firm size, etc. After deleting the incomplete schedules, a total of 488 respondents were retained for further analysis. Data were analyzed using statistical software Stata 11.

\section{Preliminary analysis of sample characteristics}

The sample comprises of 67.21 percent micro-entrepreneurs and 32.79 percent paid employees. The share of female respondents ${ }^{8}$ is about 64.29 percent in micro-entrepreneur category and about 74.82 percent in paid employee category representing a larger proportion in the total handloom labor force. Table 1 presents the

8 Large share of female in the sample is due to the fact that the handloom industry in the state is basically female intensive (NCAER 2010). 
descriptive statistics of the independent determinants used in the present study with the definition and measurement of units across categories of respondents. The sample characteristics of the total sample and the handloom micro-entrepreneurs with respect to gender are presented in Table 2.

Table 1 and Table 2 here

Results show Micro-entrepreneurs are relatively older and possess higher schooling years than the paid employee. Most of the respondents possess a high school degree while 16.60 percent are illiterate. The average number of working day in the industry is about 232 days where male respondents spend 10 percent more time in handloom activities compared to female. There exists income gaps as it is found that male respondents earns 60.68 percent more compared to female, and micro-entrepreneurs earns more by 61.95 percent compared to paid employees (Table $1 \&$ Table 2).

Present paper analyses three motivational issues i.e., work-flexibility, risk bearing ability, and financial support to family which may motivate individuals for handloom activities. Micro-entrepreneurs are found to be more risk lover by 27.66 percent than the handloom paid employee. Female micro-entrepreneurs are emerged as more risk averse compared to their male counterpart. While providing family support equally motivated rural people towards handloom micro-entrepreneurship, female respondents are motivated more by work-flexibility compared to male respondents (Table 2).

About 39.10 percent respondents perceived that they have access to capital, while 44.90 percent respondents emerged as the actual borrower in the survey year for different handloom activities. Credit access remains as major constraint in micro-enterprise development as they have 37.69 percent lower access to capital/credit. About 21.30 percent paid employee unable to achieve inter-generational sustainability (had a handloom business background, but currently working as paid employee). The credit issue is more critical for the female micro-entrepreneurs as they have lower access to capital/credit and lower practice of borrowing compared to the male micro-entrepreneurs (Table 2). The lower credit or financial activities may be explained through their low level of education, financial knowhow, and risk factors. Social/business contact is important and almost all the micro-entrepreneurs do possess the same. The average strength of the business network ${ }^{9}$ is three (3) with a quarterly interaction rate of 2.25 times in the rural areas. Here also the male micro-entrepreneurs outnumber the female in terms of size and strength of handloom business network (Table $1 \&$ Table 2). The implementation of government programs related to training and subsidy (in cash/kind) needs to be evaluated. Only 19.60 percent of the respondent reported to be benefited by training where share of male is negligible. For female, it stands at 24.60 percent only.

\section{Results and discussion}

\section{Determinants of micro-entrepreneurship entry}

Table 3 presents the MLEs in terms of marginal effects and standard coefficients of the determinants influencing the micro-entrepreneurship entry into the handloom industry. The proposed model is found significant at 1 percent level (Wald $\mathrm{Chi}^{2}$ is 165.72). The possibility of heteroskedasticity problems in the sample observations is controlled by using robust standard error (White 1980). The specification test ${ }^{10}$ was performed to examine

9 Average number of people connected with one's handloom business.

10 Link test is used here for model specification. The test is based on the significance of hatsq. as suggested by Pregibon (1980). The idea of the test is that if a regression is properly specified, one should not be able to find any additional independent determinants that are significant except by chance. 
whether the models are correctly specified or not and the results show that the models were correctly specified. Moreover, an examination of the variance inflation factor (VIF) values reveals absence of severe multicollinearity problem in the model (Table 3).

\section{Table 3 here}

The MLEs in Table 3 show that, at individual level, age, education, desire to work flexibility, risk bearing ability, availability of family labor, income from handloom activities, access to credit for handloom activities, being a borrower, family businesses background, knowing other handloom micro-entrepreneurs, business contacts in terms of people known within the handloom business, and the frequency of interaction in business are found to have significant and positive influences on micro-entrepreneurship entry in the handloom industry. On the other hand, number of working days and desire to provide monetary support to family are found to have negative influences. Due to lack of sufficient evidences, the model fails to produce significant results for access to training.

Two separate Probit models were used for male and female respondents considering the same set of independent determinants. Consistent results appear for both the model with a few exceptions. While the effect of higher level of education is found significant for male, it is nullified in the case of female. Such gender effects are found for available family labor, being actually a borrower, and frequency of interaction with the people in the handloom business chain. A reverse result is found for access to capital/credit and desire to provide financial support to the family in micro-entrepreneurship entry (Table 3).

Demographic determinants: While previous literature depict that the number of female is less than their male counterpart in entrepreneurial activities (Verheul et al. 2012; Gindling 2014), it was proposed that the situation may vary with respect to context and one may expect a reverse scenario in the sectors which are female intensive. Present study finds evidence in favor of the argument and conclude that female are more likely to enter into micro-entrepreneurial activities in the handloom industry which is female intensive. The result shows that the probability of becoming a handloom micro-entrepreneur increase by 10.30 percent for being a female, ceteris paribus ${ }^{11}$. Male individuals lack some basic skills, and existence of complexities in weaving activities decreases their probability of becoming handloom micro-entrepreneurs.

Since the nature of the industry is intergenerational which is based on imitation and knowledge spills over generation, age of the respondent is taken as a proxy for experience and used in the model as a categorical determinant. The estimate shows that the probability of being a micro-entrepreneur in the industry increases as individuals grow older and its effect is more for female, ceteris paribus. With passage of time they become more experienced about the working mechanisms of the industry which enables them to tackle different obstacles and minimize the errors in micro-entrepreneurship related activities. The influence of education in micro-entrepreneurship entry with respect to gender appears to be mixed. Somewhat surprisingly, the influence of educational attainment is not found significant for female probability to become a handloom microentrepreneur. This might be because of the labor intensive nature of the industry where weaving skills and art are more required than formal education. Yet, the role of education in micro-entrepreneurship entry is important as indicated by the positive and significant influence of possession a higher level of education on the aggregate

11 Ceteris paribus means other things being unchanged. 
sample as well as on male respondents. A higher level of education enables an individual to identify and grab better opportunities in the labor market and helps in managing the related activities efficiently.

Motivational determinants: Risk bearing ability is found significant for micro-entrepreneurship entry. As expected, its influence is found more on male compared to female respondents. The associated risk and uncertainty is perceived initially and thus get engaged with an understanding of these risks (Verheul et al. 2012). Ceteris paribus, with increase in risk taking ability of an individual by 1 unit, the probability of becoming a micro-entrepreneur increase by 6.5 percent. There involves risk of credit default if proper production activities are not taken as people in the rural areas often access credit from informal sources at much higher interest rate. There are also risks of intra-firm labor movement or measurement/weaving errors. Thus, higher positive attitude towards risk influences individuals towards handloom micro-entrepreneurship.

Though the rural areas do not provide much occupational choice, yet individuals look for flexibility in working hours particularly by the female because of household duties assigned to them. Starting a microenterprise gives opportunity to allot time on their own toward mitigating the family responsibilities which motivate people towards micro-entrepreneurship entry. The surprising negative influence of desire to provide monetary support to family on micro-entrepreneurship entry especially for female indicates that the overall fluctuations in the business performance have an impact on micro-entrepreneurs' income with a time lag against the fixed and regular income of the paid employee. This can also be explained by the poor economic condition which does not allow many households to engage in micro-entrepreneurship activities rather force towards wage employment.

Economic determinants: Family support represents the strong tie in the social capital aspects which is important in owning a micro-enterprise especially home based businesses in the rural areas. As handloom activities is labor intensive, the availability of family members as part-time laborer play important role in the microentrepreneurship entry. Present study finds a positive relation between this two. Availability of family members who can serve as part-time laborer is emerged more important for male respondents. This might be because of male perceive to be far behind in some basic skills of weaving activities while female do possess the same as intergenerational knowledge and skill.

Income of the individual emerges crucial towards RNFM entry. Higher income level gives individuals a lot of financial strength, borrowing ability, and confident to open up a microenterprise on their own or take over the family business (Bortamuly et al. 2013). Moreover, a higher level of income makes individuals selfreliant and empowered, particularly the rural female, which influence them in making decision towards microentrepreneurial activities.

The influence of access to capital/credit is found significant in micro-entrepreneurship entry. Ceteris paribus, with access to capital/credit facility, the probability of becoming micro-entrepreneurs increases by 11.3 percent. In addition, being actually a borrower is also found to have positive influence. Present study finds gender effect on access to credit and being actually a borrower in becoming a handloom micro-entrepreneur. While access to credit/capital influences female more, borrowing activity influences male more in entering into handloom business. However, it is found in the focus group discussions (FGDs) that females are more prone to credit constraints. Limited access to formal credit often force individuals to approach the informal credit sources at much higher interest rates in rural areas. Must effort is needed for financial inclusion of the rural people especially the female creating an industrial environment in the rural areas. If they can be facilitated with a 
continuous flow of credit at lower interest rates from formal institutions, one can expect faster growth and expansion of RNFM in the state. In that context, formal credit institutions may also think about specific handloom loan schemes for providing financial supports to the micro-entrepreneurs.

Social determinants: The influence of having a family business background is found significant and positive suggesting that, with such background, young people get exposure to different entrepreneurial decisions making and business operations compared to others and can avail the business contacts that their family members already have (Bhagavatula et al. 2010; Chlosta et al. 2012). As mentioned earlier, the handloom activities are based largely on imitation. Therefore, knowing other micro-entrepreneur may have spillover effect on individuals to opt handloom micro-entrepreneurship. Moreover, the linkage with the supply chain and marketing agents forms the business network which is one of the important aspects of social capital. Along with this, the interactions with the agents refer the strength of social capital. Present study finds significant influences for all these aspects indicating the importance of social capital in the development of micro-entrepreneurship. It is found that the male micro-entrepreneurs are more acquainted with the handloom business network, and the influence of the social capital variables are found to be more in case of male compared to that of female respondents. Male respondents interact frequently with the agents in the handloom business chain which has a positive impact in choosing micro-entrepreneurship as their occupation. However, its impact is nullified in case of female respondents. One possible explanation could be the presence of male members in such activities of the female owned business. In rural areas, often the business related decisions and transactions are taken by male family members.

The effect of social capital is intangible but significant in determining entrepreneurial entry, growth, and expansion (Runyan et al. 2004). The relationship with business agents helps in resolving many handloom business related problems and also important from the view point of achieving comparative advantage and business growth in the market. It acts as a medium of gathering information and knowledge related to prices, inputs, market demand, market destinations, etc., which positively influence the business performance. Due to lack of such contacts/information, many of the rural micro-entrepreneurs often find difficulties in earning the minimal profit as a result of exploitations by the master weaver, handloom traders, and other middlemen. This may force rural people to stay away from handloom micro-entrepreneurship.

Institutional determinants: Access to training facilities is taken as the only institutional determinants and expected to have positive and significant influence on rural individuals in micro-entrepreneurship entry in the handloom industry. Surprisingly, its influence appears to be not significant in the present study. While it shows a positive association with micro-entrepreneurship entry in the analyses for aggregate and female data, a negative relation is found for the male respondents. These unorthodox results may indicate an environment where there exist a perception for positive contribution of training programs on micro-entrepreneurship entry in general but at individual level these programs may appear to be ineffective or insufficient. Though effort is made at government level to disseminate technological, financial, and marketing know-how, these are limited. Absence of follow-up programs in place hinders the modern technology adoption making many training programs ineffective in rural areas.

The study reveals that a significant proportion of the micro-entrepreneurs in the rural areas are working with traditional looms such as throw shuttle looms, fly shuttle looms, ordinary frame looms, etc., as the production tools. In contrast, presence of modern machineries such as dobby, jacquard, drums, spinning 
machine, reeling machine, etc., are negligible. Moreover, most of the micro-entrepreneurs are unable to apply their skills properly due to lack of infrastructures, maintenance, and credit constraints. Therefore, present study argues that policies should be handloom community specific with flexibility in its implementation under strong monitoring provision. Provision of training will not help alone if no proper follow-up programs are in place in adopting the modern technologies.

\section{Conclusions}

In spite of policy attention and notable efforts towards promoting the rural non-farm microentrepreneurship, there exists paucity of understanding about why some people in the rural areas enter into entrepreneurial activities while others not. A little is known about the gender issues in such context. This urge for more studies with policy prescriptions which facilitates effective strategies to implement the related development programs for promoting rural noon-farm micro-entrepreneurship especially for female. Present study attempts to address this gap by providing empirical evidences towards RNFM entry focusing in gender issue.

Present study reveals a few interesting findings which have policy implications. Against the conventional wisdom that males outnumber females in entrepreneurial activities (Verheul et al. 2012), present study reveals that the situation may vary with respect to context and one may expect a reverse scenario in the rural non-farm sectors which are female intensive such as handloom. As a productive industry, policies need to be more specific to its entitlements and promotion as the industry may emerge as a medium to address the gender inequality in labor market participation. The results also reveal that there exist some differences with respect to magnitude and direction of a few determinants across gender which needs to be addressed through proper policy design. Somewhat surprisingly, the influence of educational attainment is not found significant for female's probability to become a handloom micro-entrepreneur. This also replicated in the influences of borrowings, available family members, and interaction with the business agents.

Present study shows that the efficient functional relationship with the supply chain agents at different points of business operation is vital towards RNFM development. A mix of co-operative and competitive business network structure with distinct strategies give rise to comparative advantage in market. While credit/capital access appears to be significant in micro-entrepreneurship development, such facilities are limited in rural areas depicting the need of financial inclusion of the rural people especially the female. Facilitation of continuous flow of formal as well as informal credit will foster the expansion of rural micro-entrepreneurship in the state. It is also important to monitor the proper use of institutional credit and here comes the role of extension services. Despite efforts are being made to disseminate technological, financial, and marketing knowhow, use of traditional technology (looms) is still prominent in rural areas leaving the use of modern machineries in fringe. The absence of follow-up programs in place, lack of infrastructures, maintenance, and credit constraints hinder the modern technology adoption making the ongoing training related programs ineffective in the rural areas. Thus, the implementation of government programs related to training and assistance (in cash/kind) need to be checked. Present study argues for handloom community specific policies with flexibility in implementation under strong monitoring provision. This is because of the fact that provision of training will not help alone if no proper follow-up programs are in place in adopting the modern technologies.

The study contributes to the literature by providing empirical evidences towards non-farm rural microentrepreneurship entry decisions drawing insights from an under researched context of handloom industry. In 
spite of taking utmost care, the study is not free from limitations. The study is based on cross sectional data considering single industry. Complete understanding of RNFM entry and addressing the causes of gender differences needs further studies extending the scope beyond handloom industries within the context of informality.

\section{References}

Acs, Z. J., Svejnar, J., Bardasi, E., \& Estrin, S. (2011). Introduction to special issue of Small Business Economics on female entrepreneurship in developed and developing economies. Small Business Economics, 37, 393-396.

Aguayo-Tellez, E., Airola, J., Juhn, C., \& Villegas-Sanchez, C. (2013). Did trade liberalization help women? The case of Mexico in the 1990s. Research in Labor Economics, 38, 1-35.

Amorós, J. E., \& Bosma, N. (2014). Global Entrepreneurship Monitor 2013 Global Report. Global Entrepreneurship Research Association (GERA). London, UK: London Business School.

Baumol, W. J. (1990). Entrepreneurship: productive, unproductive and destructive. Journal of Political Economy, 98(5), 893-921.

Bhagavatula, S., Elfring, T., Tilburg, A., \& Bunt, G. G. (2010). How social and human capital influence opportunity recognition and resource mobilization in India's handloom industry. Journal of Business Venturing, 25 (3), 245-260.

Bharadwaj, L., Findeis, J. L., \& Chintawar, S. (2013). Motivations to work off-farm among U.S. farm women. The Journal of Socio-Economics, 45, 71-77.

Bortamuly, A. B., Goswami, K., \& Hazarika, B. (2013). Determinants of occupational choice of workers in handloom industry in Assam. International Journal of Social Economics, 40(12), 1041-1057.

Bruder, J., Neuberger, D., \& Rathke-Doppner, S. (2011). Financial constraints of ethnic entrepreneurship: evidence from Germany. International Journal of Entrepreneurial Behaviour \& Research, 17(3), 296313.

Cahill, K., Giandrea, M., \& Quinn, J. (2013). New evidence on self-employment transitions among older Americans with career jobs. U.S. Bureau of Labor Statistics Working Paper 463. Washington: U.S. Department of Labor.

Carr, J. C., \& Sequeira, J. M. (2007). Prior family business exposure as intergenerational influence and entrepreneurial intent: a theory of planned behavior approach. Journal of Business Research, 60(10), 1090-1098.

Chlosta, S., Patzelt, H., Klein, S. B., \& Dormann, C. (2012). Parental role models and the decision to become self-employed: the moderating effect of personality. Small Business Economics, 38(1), 121-138.

Contessi, S., Nicola, F., \& Li, L. (2013). International trade, female labor, and entrepreneurship in MENA countries. Federal Reserve Bank of St. Louis Review, 95(1), 89-114.

Directorate of Economics and Statistics (2011). Statistical Handbook of Assam 2010. Guwahati, India: Government of Assam.

Douglas, E., \& Shepherd, D. (2002). Self-employment as a career choice: attitudes, entrepreneurial intentions, and utility maximization. Entrepreneurship Theory and Practice, 26(3), 81-90.

Duberley, J., \& Carrigan, M. (2013). The career identities of 'mumpreneurs': women's experiences of combining enterprise and motherhood. International Small Business Journal, 31(6), 629-651. 
Dunn, T., \& Holtz-Eakin, D. (2000). Financial capital, human capital and the transition to self-employment: evidence from intergenerational links. Journal of Labor Economics, 18(2), 282-305.

Georgellis, Y., \& Wall, H. (2005). Gender differences in self-employment. International Review of Applied Economics, 19(3), 321-342.

Gindling, T. H. (2014). Self-employment in the developing world. World Development, 56, 313-331.

Gujarati, D. (2003). Basic Econometrics (4 ${ }^{\text {th }}$ ed.). New York: Tata McGraw Hill.

Hellmann, T., \& Puri, M. (2002). Venture capital and the professionalization of start-up firms: empirical evidence. Journal of Finance, 57(1), 169-197.

Kevane, M., \& Wydick, B. (2001). Microenterprise lending to female entrepreneurs: sacrificing economic growth for poverty alleviation? World Development, 29(7), 1225-1236.

Kotha, R., \& George, G. (2012). Friends, family, or fools: entrepreneur experience and its implications for equity distribution and resource mobilization. Journal of Business Venturing, 25(5), 525-543.

Leoni, T., \& Falk, M. (2010). Gender and field of study as determinants of self-employment. Small Business Economics, 34(2), 167-185.

Liedholm, C. (2002). Small firm dynamics: evidence from Africa and Latin America. Small Enterprise Development, 18(1-3), 227-242.

Liñán, F., Rodríguez-Cohard, J. C., \& Rueda-Cantuche, J. M. (2011). Factors affecting entrepreneurial intention levels: a role for education. International Entrepreneurship and Management Journal, 7(2), 195-218.

Lofstrom, M., Bates, T., \& Parker, S. C. (2014). Why are some people more likely to become small-businesses owners than others: entrepreneurship entry and industry-specific barriers. Journal of Business Venturing, 29(2), 232-251.

Mahmood, T. (2009). Technical and Vocational Education and Training: Issues, Concerns and Prospects. Netherlands: Springer.

McGowan, P., Redeker, C. L., Cooper S. Y., \& Greenan, K. (2012). Female entrepreneurship and the management of business and domestic roles: Motivations, expectations and realities. Entrepreneurship \& Regional Development: An International Journal, 24(1-2), 53-72.

Mehta, A., \& Mehta, M. C. (2011). Rural women entrepreneurship in India: opportunities and challenges. International Conference on Humanities, Geography and Economics, Pattaya, Thailand. Available at http://psrcentre.org/images/extraimages/1211306.pdf

Nachimuthu, G. S., \& Gunatharan, B. (2012). Empowering women through entrepreneurship: a study in Tamil Nadu, India. International Journal of Trade, Economics and Finance, 3(2), 143-147.

NCAER (2010). Handloom Census 2009-10. New Delhi: Development Commissioner for Handlooms, Government of India.

Niranjana, S. (2001). Appraising of Indian handloom industry. Economic and Political Weekly, 36(45), 42484250.

Obschonka, M., Silbereisen, R. K., Schmitt-Rodermund, E., \& Stuetzer, M. (2011). Nascent entrepreneurship and the developing individual: early entrepreneurial competence in adolescence and venture creation success during the career. Journal of Vocational Behavior 79(1), 121-133

Oostendorp, R. H. (2009). The changing role of non-farm household enterprises in Vietnam. World Development, 37(3), 632-644. 
Parker, S. (2009). The Economics of Entrepreneurship. Cambridge: Cambridge University Press.

Peris-Ortiz, M., Rueda-Armengot, C., \& Osorio, D. B. (2012). Women in business: entrepreneurship, ethics and efficiency. International Entrepreneurship and Management Journal, 8(3), 343-354.

Poschke, M. (2013). Entrepreneurs out of necessity: a snapshot. Applied Economics Letters, 20(7), 658-663.

Pregibon, D. (1980). Goodness of link tests for generalized linear models. Journal of the Royal Statistical Society, Series C (Applied Statistics), 29(1), 15-23.

Rijkers, B., \& Costa, R. (2012). Gender and rural non-farm entrepreneurship. World Development 40(12), 24112426.

Rothstein, B., \& Stolle, D. (2002). How political institutions create and destroy social capital: an institutional theory of generalized trust. Paper presented at the 98th Meeting of the American Political Science Association, Boston, 29 ${ }^{\text {th }}$ August - 2nd September.

Runyan, R. C., Huddleston, P., \& Swinney, J. (2004). Entrepreneurial orientation and social capital as small firm strategies: a study of gender differences from a resource-based view. Entrepreneurship Management, 2(4), 455-477.

Saridakis, G., Marlow, S., \& Storey, D. J. (2014). Do different factors explain male and female self-employment rates? Journal of Business Venturing, 29(3), 345-362.

Schroder, E., \& Schmitt-Rodermund, E. (2013). Antecedents and consequences of adolescents' motivations to join the family business. Journal of Vocational Behavior 83(3), 476-485.

Simoes, N., Moreira, S. B., \& Crespo, N. (2013). Individual determinants of self-employment entry: what do we really know? MPRA Paper No. 48403, UTC. Available at http://mpra.ub.uni-muenchen.de/48403/

Stel, A., Storey, D. J. \& Thurik, A. R. (2007). The effect of business regulations on nascent and young business entrepreneurship. Small Business Economics, 28(2-3), 171-186.

Syamasundari, B.., \& Niranjana, S. (2006). Valuing the non-market. Economic and Political weekly, 41(31), 3394-3398.

Thai, M. T. T., \& Turkina1, E. (2013). Macro-level determinants of formal entrepreneurship versus informal entrepreneurship. Journal of Business Venturing. doi http://dx.doi.org/10.1016/j.jbusvent.2013.07.005

Thompson, P., Jones-Evans, D., \& Kwong, C. (2009). Women and home-based entrepreneurship: evidence from the United Kingdom. International Small Business Journal, 27(2), 227-239.

UN (2010). The World's Women 2010: Trends and Statistics. New York: United Nations Publication.

Verheul, I., Thurik, R., Grilo, I., \& Zwan, P. (2012). Explaining preferences and actual involvement in selfemployment: gender and the entrepreneurial personality. Journal of Economic Psychology, 33(2), 325341.

Vossenberg, S. (2013). Women entrepreneurship promotion in developing countries: what explains the gender gap in entrepreneurship and how to close it? Working Paper No. 2013/08. The Netherlands: Maastricht School of Management.

Webb, J. W., Bruton, G. D, Tihanyi, L., \& Ireland, R. D. (2013). Research on entrepreneurship in the informal economy: framing a research agenda. Journal of Business Venturing, 28(5), 598-614.

Welter, F., \& Smallbone, D. (2008). Women's entrepreneurship from an institutional perspective: the case of Uzbekistan. International Entrepreneurship and Management Journal, 4(4), 505-520. 
White, H. (1980). A heteroskedasticity-consistent covariance matrix estimator and a direct test for heteroskedasticity. Econometrica, 48(4), 817-838.

Williams, C. C., \& Gurtoo, A. (2011). Evaluating women entrepreneurs in the informal sector: some evidence from India. Journal of Developmental Entrepreneurship, 16(3), 351-369.

Wooldridge, J. M. (2009). Introductory Econometrics ( $4^{\text {th }}$ Eds.). Delhi: Cengage Learnng.

Wydick, B., Hayes, H. K., \& Kempf, S. H. (2011). Social networks, neighborhood effects, and credit access: evidence from rural Guatemala. World Development, 39(6), 974-982.

Study Area

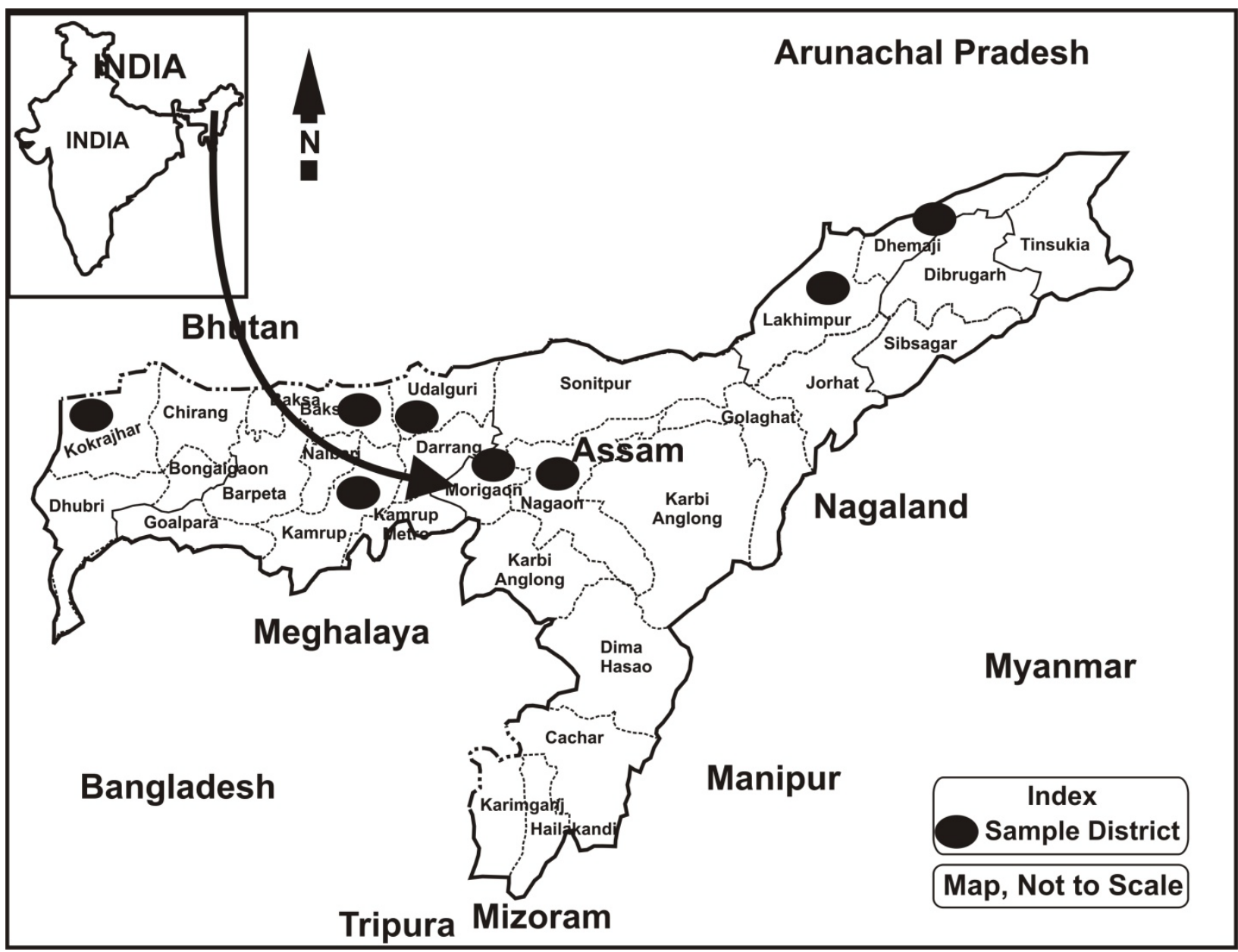

Map. Study area showing the sample districts 
Table 1. Descriptive statistics of the determinants of handloom micro-entrepreneurship development

\begin{tabular}{|c|c|c|c|c|c|c|c|c|c|c|}
\hline & \multirow{2}{*}{ Variables } & \multirow{2}{*}{ Definition (Unit) } & \multicolumn{2}{|c|}{$\begin{array}{c}\text { Combined sample } \\
\text { (488) }\end{array}$} & \multicolumn{2}{|c|}{$\begin{array}{l}\text { Micro-entrepreneur } \\
\text { (328) }\end{array}$} & \multicolumn{2}{|c|}{$\begin{array}{l}\text { Paid employee } \\
(160)\end{array}$} & \multicolumn{2}{|c|}{ Statistical difference } \\
\hline & & & Mean & $\begin{array}{l}\text { Std. } \\
\text { Dev. }\end{array}$ & Mean & $\begin{array}{l}\text { Std. } \\
\text { Dev. }\end{array}$ & Mean & $\begin{array}{l}\text { Std. } \\
\text { Dev. }\end{array}$ & $\begin{array}{l}\text { t-value } \\
\text { (t-test) }\end{array}$ & Pearson $\mathrm{Chi}^{2}$ \\
\hline \multirow{10}{*}{$\begin{array}{l}\text { Personal } \\
\text { determinants }\end{array}$} & Gender & $\begin{array}{l}\text { Sex of the respondent } \\
\text { ( } 1 \text { for female and } 0 \text { for male ) }\end{array}$ & 0.717 & 0.451 & 0.686 & 0.465 & 0.781 & 0.415 & -- & $4.813^{* *}$ \\
\hline & Age & Age of the respondents (year) & 34.826 & 9.205 & 36.670 & 9.000 & 31.050 & 8.470 & $6.600^{* * *}$ & -- \\
\hline & Age 1\# & Age group1 (18-30 year) & 38.520 & 0.487 & 58.130 & 0.454 & 28.960 & 0.495 & -- & $38.615^{* * *}$ \\
\hline & Age 2\# & Age group1 (30-45 year) & 43.440 & 0.496 & 33.750 & 0.500 & 48.170 & 0.474 & -- & $9.102^{* * *}$ \\
\hline & Age 3\# & Age group1 (45 year and above) & 18.040 & 0.385 & 8.130 & 0.421 & 22.870 & 0.274 & -- & $15.809^{* * *}$ \\
\hline & Education & Years spent in school (year) & 7.303 & 4.322 & 8.027 & 4.140 & 5.819 & 4.319 & $5.545^{* * *}$ & -- \\
\hline & Illiterate\# & No schooling & 16.600 & 0.372 & 25.630 & 0.328 & 12.200 & 0.438 & -- & $14.011^{* * *}$ \\
\hline & Primary\# & 1 to 7 years & 27.050 & 0.445 & 31.250 & 0.434 & 25.000 & 0.465 & -- & 2.129 \\
\hline & High school\# & 8 to 11 years & 38.110 & 0.486 & 35.000 & 0.490 & 39.630 & 0.478 & -- & 0.979 \\
\hline & $\begin{array}{l}\text { Higher } \\
\text { Secondary+\# }\end{array}$ & 12 years and more & 18.240 & 0.387 & 8.130 & 0.423 & 23.170 & 0.274 & -- & $16.326^{* * *}$ \\
\hline \multirow{3}{*}{$\begin{array}{l}\text { Motivational } \\
\text { determinants }\end{array}$} & Family Support & $\begin{array}{l}\text { Desire provide support to family } \\
\text { (index value } 1 \text { to 5) }\end{array}$ & 3.898 & 0.903 & 3.745 & 0.980 & 4.211 & 0.611 & $-5.513^{* * *}$ & -- \\
\hline & Work-flexibility & $\begin{array}{l}\text { Desire to achieve work flexibility } \\
\text { (index value } 1 \text { to } 5 \text { ) }\end{array}$ & 3.915 & 0.936 & 3.934 & 0.930 & 3.875 & 0.948 & 0.659 & -- \\
\hline & Risk Attitude & $\begin{array}{l}\text { Risk bearing ability } \\
\text { (index value } 1 \text { to } 5 \text { ) }\end{array}$ & 3.318 & 1.066 & 3.572 & 0.970 & 2.798 & 1.069 & $8.001^{* * *}$ & -- \\
\hline \multirow{5}{*}{$\begin{array}{l}\text { Economic } \\
\text { determinants }\end{array}$} & Part-time & $\begin{array}{l}\text { Availability of family member as part-time } \\
\text { worker (number) }\end{array}$ & 0.738 & 0.809 & 0.890 & 0.831 & 0.425 & 0.659 & $6.191^{* * *}$ & -- \\
\hline & Working day & Working days in a year (numbers) & 232.521 & 50.268 & 228.524 & 51.388 & 240.713 & 46.991 & $-2.528 * *$ & -- \\
\hline & Income & $\begin{array}{l}\text { Annual income of the respondents (Thousand } \\
\text { Indian Rupee) }\end{array}$ & 35.045 & 27.801 & 40.071 & 31.189 & 24.743 & 14.414 & $5.913 * * *$ & -- \\
\hline & Access to Capital\# & $\begin{array}{l}\text { Access to capital } \\
\text { ( } 1 \text { for yes and } 0 \text { for no) }\end{array}$ & 0.391 & 0.489 & 0.515 & 0.501 & 0.138 & 0.345 & -- & $64.420 * * *$ \\
\hline & Borrower\# & $\begin{array}{l}\text { Actually borrowed capital in the last year ( } 1 \text { for } \\
\text { yes and } 0 \text { for no) }\end{array}$ & 0.449 & 0.498 & 0.555 & 0.498 & 0.231 & 0.423 & -- & $45.531^{* * *}$ \\
\hline \multirow{4}{*}{$\begin{array}{l}\text { Social } \\
\text { determinants }\end{array}$} & Past Business\# & $\begin{array}{l}\text { Family handloom business background } \\
\text { (1 for yes and } 0 \text { for no) }\end{array}$ & 0.375 & 0.485 & 0.454 & 0.499 & 0.213 & 0.410 & -- & $26.820 * * *$ \\
\hline & Knowing & $\begin{array}{l}\text { Knowing other handloom micro-entrepreneurs ( } 1 \\
\text { for yes and } 0 \text { for no) }\end{array}$ & 0.887 & 0.317 & 0.976 & 0.154 & 0.706 & 0.457 & -- & $78.024^{* * *}$ \\
\hline & Contacts & $\begin{array}{l}\text { Having handloom business contacts with people } \\
\text { (number) }\end{array}$ & 2.945 & 2.211 & 3.753 & 2.030 & 1.288 & 1.548 & $13.561^{* * *}$ & -- \\
\hline & Frequency & Frequency of interaction in a quarter (number) & 2.252 & 1.813 & 2.863 & 1.728 & 1.000 & 1.254 & $12.159^{* * *}$ & -- \\
\hline $\begin{array}{l}\text { Institutional } \\
\text { determinant }\end{array}$ & Training\# & $\begin{array}{ll}\text { Availed institutional training handloom on } \\
\text { handloom ( } 1 \text { for yes and } 0 \text { for no) }\end{array}$ & 0.199 & 0.399 & 0.207 & 0.406 & 0.181 & 0.386 & -- & 0.459 \\
\hline
\end{tabular}

${ }^{\#}$ Figures of the variables represent percentage of total sample in the categories. ${ }^{* * *} \mathrm{p}<0.01{ }^{* *} \mathrm{p}<0.05 ;{ }^{*} \mathrm{p}<0.10$. 
Table 2. Mean and proportion test of the determinants of handloom micro-entrepreneurship development across gender

\begin{tabular}{|c|c|c|c|c|c|c|c|c|c|c|c|c|c|}
\hline \multirow{3}{*}{\multicolumn{2}{|c|}{ Determinants }} & \multicolumn{6}{|c|}{ All respondents } & \multicolumn{6}{|c|}{ Micro-entrepreneurs } \\
\hline & & \multicolumn{2}{|c|}{ Male (138) } & \multicolumn{2}{|c|}{ Female (350) } & \multicolumn{2}{|c|}{ Statistical difference } & \multicolumn{2}{|c|}{ Male (103) } & \multicolumn{2}{|c|}{ Female (205) } & \multicolumn{2}{|c|}{ Statistical difference } \\
\hline & & Mean & $\begin{array}{l}\text { Std. } \\
\text { Dev. }\end{array}$ & Mean & $\begin{array}{l}\text { Std. } \\
\text { Dev. }\end{array}$ & $\begin{array}{l}\text { t-value } \\
\text { (t-test) }\end{array}$ & Pearson $\mathrm{Chi}^{2}$ & Mean & $\begin{array}{l}\text { Std. } \\
\text { Dev. }\end{array}$ & Mean & $\begin{array}{l}\text { Std. } \\
\text { Dev. }\end{array}$ & $\begin{array}{c}\mathrm{t} \text {-value } \\
\text { (t-test) }\end{array}$ & Pearson Chi \\
\hline \multirow{9}{*}{$\begin{array}{l}\text { Personal } \\
\text { determinants }\end{array}$} & Age & 36.616 & 9.580 & 34.120 & 8.969 & $2.715^{* * *}$ & -- & 38.427 & 9.620 & 35.862 & 8.600 & $2.414^{* *}$ & -- \\
\hline & $18-30$ years\# & 34.060 & 0.476 & 40.290 & 0.491 & -- & 1.621 & 0.262 & 0.442 & 0.302 & 0.460 & -- & 1.122 \\
\hline & $30-45$ years\# & 40.580 & 0.493 & 44.570 & 0.498 & -- & 0.642 & 0.417 & 0.496 & 0.511 & 0.501 & -- & 0.552 \\
\hline & 45 years+\# & 25.360 & 0.437 & 15.140 & 0.359 & -- & $6.993 * * *$ & 0.320 & 0.469 & 0.187 & 0.391 & -- & 2.481 \\
\hline & Education & 8.174 & 4.230 & 6.960 & 4.315 & $2.814^{* * *}$ & -- & 9.126 & 3.793 & 7.524 & 4.203 & $3.301^{* * *}$ & -- \\
\hline & Illiterate\# & 11.590 & 0.321 & 18.570 & 0.389 & -- & $3.481^{*}$ & 0.058 & 0.235 & 0.151 & 0.359 & -- & $5.690^{* *}$ \\
\hline & Primary\# & 24.640 & 0.432 & 28.000 & 0.450 & -- & 0.567 & 0.233 & 0.425 & 0.258 & 0.438 & -- & 0.231 \\
\hline & High school\# & 37.680 & 0.486 & 38.290 & 0.487 & -- & 0.015 & 0.379 & 0.487 & 0.404 & 0.492 & -- & 0.197 \\
\hline & Higher Secondary+\# & 26.090 & 0.441 & 15.140 & 0.359 & -- & $7.950 * * *$ & 0.330 & 0.473 & 0.187 & 0.391 & -- & $8.165^{* * *}$ \\
\hline \multirow{3}{*}{$\begin{array}{l}\text { Motivational } \\
\text { determinants }\end{array}$} & Family Support & 3.845 & 0.919 & 3.919 & 0.897 & -0.814 & -- & 3.732 & 0.953 & 3.751 & 0.995 & -0.163 & -- \\
\hline & Work-flexibility & 3.543 & 1.051 & 4.061 & 0.844 & $-5.682 * * *$ & -- & 3.529 & 1.036 & 4.120 & 0.815 & $-5.581 * * *$ & -- \\
\hline & Risk Attitude & 3.601 & 1.099 & 3.207 & 1.034 & $3.732 * * *$ & -- & 3.832 & 0.996 & 3.453 & 0.936 & $3.330^{* * *}$ & -- \\
\hline \multirow{5}{*}{$\begin{array}{l}\text { Economic } \\
\text { determinants }\end{array}$} & Part-time & 0.870 & 0.844 & 0.686 & 0.789 & $2.272^{* *}$ & -- & 1.068 & 0.820 & 0.809 & 0.826 & $2.643^{* * *}$ & -- \\
\hline & Working day & 248.674 & 52.523 & 226.151 & 47.951 & $4.547^{* * *}$ & -- & 245.709 & 56.174 & 220.658 & 47.119 & $4.201^{* * *}$ & -- \\
\hline & Income & 47.145 & 38.820 & 30.274 & 20.155 & $6.270^{* * *}$ & -- & 53.039 & 42.744 & 34.134 & 21.803 & $5.302 * * *$ & -- \\
\hline & Access to Capital\# & 0.536 & 0.501 & 0.334 & 0.472 & -- & $16.945^{* * *}$ & 0.631 & 0.485 & 0.462 & 0.500 & -- & $8.065^{* * *}$ \\
\hline & Borrower\# & 0.551 & 0.499 & 0.409 & 0.492 & -- & $8.085^{* * * *}$ & 0.680 & 0.469 & 0.498 & 0.501 & -- & $9.458^{* * *}$ \\
\hline \multirow{4}{*}{ Social determinants } & Past Business\# & 0.355 & 0.480 & 0.383 & 0.487 & -- & 0.326 & 0.398 & 0.492 & 0.480 & 0.501 & -- & 1.914 \\
\hline & Knowing \# & 0.913 & 0.283 & 0.877 & 0.329 & -- & 1.276 & 0.971 & 0.169 & 0.978 & 0.148 & -- & $0710^{\$}$ \\
\hline & Contacts & 3.877 & 2.556 & 2.577 & 1.944 & $6.058^{* * *}$ & -- & 4.709 & 2.286 & 3.316 & 1.738 & $6.079 * * *$ & -- \\
\hline & Frequency & 2.957 & 2.036 & 1.974 & 1.638 & $5.554 * * *$ & -- & 3.573 & 1.866 & 2.538 & 1.561 & $5.233^{* * *}$ & -- \\
\hline $\begin{array}{l}\text { Institutional } \\
\text { determinant }\end{array}$ & Training\# & 0.080 & 0.272 & 0.246 & 0.431 & -- & $17.126^{* * * *}$ & 0.078 & 0.269 & 0.267 & 0.443 & -- & $15.358^{* * *}$ \\
\hline
\end{tabular}

\# Figures of the variables represent percentage of total sample in the categories.*** ${ }^{*}<0.01 ;{ }^{* *} \mathrm{p}<0.05 ;{ }^{*} \mathrm{p}<0.10{ }^{\$}$ Fisher exact p-value is estimated due to violation of Chi ${ }^{2}$ assumption of minimum expected value of each cell (5). Fisher's exact test does not have a "test statistic", but computes the p-value directly. 
Table 3. Probit estimates of determinants influencing handloom micro-entrepreneurship entry

\begin{tabular}{|c|c|c|c|c|c|c|c|c|c|c|}
\hline & \multirow[b]{2}{*}{ Determinants } & \multicolumn{3}{|c|}{ All } & \multicolumn{3}{|c|}{ Male } & \multicolumn{3}{|c|}{ Female } \\
\hline & & $\begin{array}{c}\text { Marginal } \\
\text { effect }\end{array}$ & $\begin{array}{c}\text { Coef. } \\
\text { (Std. Err.) }\end{array}$ & VIF & $\begin{array}{c}\text { Marginal } \\
\text { effect }\end{array}$ & $\begin{array}{c}\text { Coef. } \\
\text { (Std. Err.) }\end{array}$ & VIF & $\begin{array}{c}\text { Marginal } \\
\text { effect }\end{array}$ & $\begin{array}{c}\text { Coef. } \\
\text { (Std. Err.) }\end{array}$ & VIF \\
\hline \multirow{6}{*}{$\begin{array}{l}\text { Personal } \\
\text { determinants }\end{array}$} & Gender & 0.103 & $\begin{array}{l}0.463 * * \\
(0.222)\end{array}$ & 1.340 & & & & & & \\
\hline & $30-45$ years & 0.130 & $\begin{array}{l}0.685^{* * * *} \\
(0.191)\end{array}$ & 1.380 & 0.001 & $\begin{array}{l}1.793^{* * * *} \\
(0.557)\end{array}$ & 1.58 & 0.183 & $\begin{array}{l}0.729 * * * \\
(0.208)\end{array}$ & 1.58 \\
\hline & 45 years + & 0.168 & $\begin{array}{l}1.417^{* * * *} \\
(0.319)\end{array}$ & 1.490 & 0.002 & $\begin{array}{l}3.692 * * * \\
(0.953)\end{array}$ & 1.66 & 0.205 & $\begin{array}{l}1.222 * * * \\
(0.409)\end{array}$ & 1.66 \\
\hline & Primary & 0.032 & $\begin{array}{l}0.171 \\
(0.286)\end{array}$ & 2.070 & 0.001 & $\begin{array}{l}1.016 \\
(0.830)\end{array}$ & 2.92 & 0.049 & $\begin{array}{l}0.194 \\
(0.317)\end{array}$ & 2.92 \\
\hline & High school & 0.065 & $\begin{array}{l}0.343 \\
(0.281)\end{array}$ & 2.400 & 0.001 & $\begin{array}{l}2.207 * * * \\
(0.725)\end{array}$ & 3.61 & 0.052 & $\begin{array}{l}0.206 \\
(0.320)\end{array}$ & 3.61 \\
\hline & Higher Secondary + & 0.111 & $\begin{array}{l}0.737 * * \\
(0.360)\end{array}$ & 2.210 & 0.001 & $\begin{array}{l}3.195 * * * \\
(0.848)\end{array}$ & 3.48 & 0.134 & $\begin{array}{l}0.648 \\
(0.421)\end{array}$ & 3.48 \\
\hline \multirow{3}{*}{$\begin{array}{l}\text { Motivational } \\
\text { determinants }\end{array}$} & Family Support & -0.063 & $\begin{array}{l}-0.319 * * \\
(0.125)\end{array}$ & 1.560 & 0.001 & $\begin{array}{l}-0.378 \\
(0.284)\end{array}$ & 1.55 & -0.106 & $\begin{array}{l}-0.406 * * \\
(0.162)\end{array}$ & 1.55 \\
\hline & Work-flexibility & 0.077 & $\begin{array}{l}0.388 * * * \\
(0.117)\end{array}$ & 1.360 & 0.001 & $\begin{array}{l}1.078 * * * \\
(0.326)\end{array}$ & 1.3 & 0.102 & $\begin{array}{l}0.392 * * * \\
(0.136)\end{array}$ & 1.3 \\
\hline & Risk Attitude & 0.065 & $\begin{array}{l}0.327 * * * \\
(0.084)\end{array}$ & 1.220 & 0.001 & $\begin{array}{l}0.685^{* * *} \\
(0.258)\end{array}$ & 1.34 & 0.077 & $\begin{array}{l}0.294^{* * *} \\
(0.099)\end{array}$ & 1.34 \\
\hline \multirow{5}{*}{$\begin{array}{l}\text { Economic } \\
\text { determinants }\end{array}$} & Part-time Family Member & 0.052 & $\begin{array}{l}0.260^{* *} \\
(0.127)\end{array}$ & 1.180 & 0.001 & $\begin{array}{l}1.355^{* * * *} \\
(0.384)\end{array}$ & 1.23 & 0.025 & $\begin{array}{l}0.094 \\
(0.132)\end{array}$ & 1.23 \\
\hline & Working day & -0.001 & $\begin{array}{l}-0.006 * * \\
(0.002)\end{array}$ & 1.230 & 0.001 & $\begin{array}{l}-0.017 * * \\
(0.008)\end{array}$ & 1.25 & -0.002 & $\begin{array}{l}-0.007 * * \\
(0.003)\end{array}$ & 1.25 \\
\hline & Income & 0.008 & $\begin{array}{l}0.041 * * * \\
(0.007)\end{array}$ & 1.390 & 0.001 & $\begin{array}{l}0.043 * * * \\
(0.017)\end{array}$ & 1.42 & 0.014 & $\begin{array}{l}0.052 * * * \\
(0.010)\end{array}$ & 1.42 \\
\hline & Access to Capital & 0.113 & $\begin{array}{l}0.610 * * * \\
(0.221)\end{array}$ & 1.390 & 0.001 & $\begin{array}{l}0.301 \\
(0.484)\end{array}$ & 1.32 & 0.161 & $\begin{array}{l}0.689 * * * \\
(0.267)\end{array}$ & 1.32 \\
\hline & Borrower & 0.093 & $\begin{array}{l}0.480 * * * \\
(0.182)\end{array}$ & 1.180 & 0.007 & $\begin{array}{l}2.455^{* * * *} \\
(0.769)\end{array}$ & 1.41 & 0.083 & $\begin{array}{l}0.328 \\
(0.200)\end{array}$ & 1.41 \\
\hline \multirow{4}{*}{$\begin{array}{l}\text { Social } \\
\text { determinants }\end{array}$} & Past Business & 0.086 & $\begin{array}{l}0.459 * * \\
(0.187)\end{array}$ & 1.070 & 0.001 & $\begin{array}{l}0.985^{*} \\
(0.581)\end{array}$ & 1.16 & 0.115 & $\begin{array}{l}0.464 * * * \\
(0.209)\end{array}$ & 1.16 \\
\hline & $\begin{array}{l}\text { Knowing other } \\
\text { entrepreneurs }\end{array}$ & 0.619 & $\begin{array}{l}1.922 * * * \\
(0.453)\end{array}$ & 1.150 & 0.147 & $\begin{array}{l}3.038^{*} \\
(1.715)\end{array}$ & 1.27 & 0.743 & $\begin{array}{l}2.273^{* * *} \\
(0.596)\end{array}$ & 1.27 \\
\hline & Business Contacts & 0.048 & $\begin{array}{l}0.239 * * * \\
(0.078)\end{array}$ & 2.130 & 0.001 & $\begin{array}{l}0.600^{*} \\
(0.313)\end{array}$ & 2.12 & 0.061 & $\begin{array}{l}0.235^{* * *} \\
(0.091)\end{array}$ & 2.12 \\
\hline & Contact Frequency & 0.042 & $\begin{array}{l}0.210^{*} \\
(0.113) \\
\end{array}$ & 1.900 & 0.001 & $\begin{array}{l}0.704^{* * * *} \\
(0.265)\end{array}$ & 1.93 & 0.044 & $\begin{array}{l}0.167 \\
(0.129) \\
\end{array}$ & 1.93 \\
\hline $\begin{array}{l}\text { Institutional } \\
\text { determinant }\end{array}$ & Training & 0.051 & $\begin{array}{l}0.284 \\
(0.213)\end{array}$ & 1.070 & -0.001 & $\begin{array}{l}-0.767 \\
(0.877)\end{array}$ & 1.14 & 0.076 & $\begin{array}{l}0.315 \\
(0.229)\end{array}$ & 1.14 \\
\hline Constant & & & $\begin{array}{l}-5.231^{* * *} \\
(1.014) \\
\end{array}$ & & & $\begin{array}{l}-12.563^{* * * *} \\
(2.985)\end{array}$ & & & $\begin{array}{l}-4.431^{* * *} \\
(1.094)\end{array}$ & \\
\hline \multirow{6}{*}{$\begin{array}{l}\text { Model } \\
\text { summary }\end{array}$} & Observation & & 488 & & & 138 & & & 350 & \\
\hline & Wald chi2(18) & & 165.72 & & & 41.51 & & & 122.50 & \\
\hline & Prob> chi2 & & 0.001 & & & 0.001 & & & 0.001 & \\
\hline & Pseudo R2 & & 0.590 & & & 0.8158 & & & 0.561 & \\
\hline & Logpseudolikelihood & & -126.567 & & & -14.3929 & & & -99.979 & \\
\hline & ROC curve & & 0.955 & & & 0.992 & & & 0.947 & \\
\hline
\end{tabular}

*** $\mathrm{p}<0.01 ; * * \mathrm{p}<0.05 ; * \mathrm{p}<0.10$. 